\title{
Status Hematologi, Kadar IgG dan IgA Tikus yang Mengonsumsi berbagai Variasi Jumlah Tempe Kedelai Hitam
}

\author{
Status of Hematology, IgG and IgA Levels of Consuming Rats of Variations of Amount of Black Soybean Tempe \\ N. Nurrahman ${ }^{1 *}$, M. Mariyam² \\ ${ }^{1}$ Program Studi Teknologi Pangan Universitas Muhammadiyah Semarang, Jl. Kedung Mundu Raya No. 18, \\ Kedungmundu, Kecamatan Tembalang, Kota Semarang, Jawa Tengah 50273, Indonesia \\ ${ }^{2}$ Program Studi Keperawatan Universitas Muhammadiyah Semarang, Jl. Kedung Mundu Raya No. 18, \\ Kedungmundu, Kecamatan Tembalang, Kota Semarang, Jawa Tengah 50273, Indonesia \\ *Email: nurrahman@unimus.ac.id
}

Tanggal submisi: 20 Juni 2017; Tanggal penerimaan: 18 Juni 2019

\begin{abstract}
ABSTRAK
Konsumsi tempe kedelai hitam dapat memberikan perbaikan dengan cepat pada anak status gizi kurang dan/ atau menderita diare. Aktivitas antioksidan tempe kedelai hitam lebih tinggi dibanding tempe kedelai kuning. Penelitian ini bertujuan untuk mengkaji pengaruh jumlah tempe kedelai hitam di dalam pakan terhadap status hematologi, kadar IgG, dan kadar IgA darah tikus. Sebanyak 6 kelompok yang berisi 5 ekor tikus. Tikus dipelihara di laboratorium hewan dengan suhu kamar $\left(25-27^{\circ} \mathrm{C}\right)$ selama 25 hari. Enam kelompok tersebut diinduksi suspensi Enteropathogenik Eschericia coli (EPEC) dengan konsentrasi $10^{7} \mathrm{cfu} / \mathrm{mL}$ sebanyak $1 \mathrm{~mL}$ per hari selama tujuh hari, secara oral menggunakan sonde. Parameter yang dianalisa antara lain status hematologi, kadar IgG dan kadar IgA. Pemberian tempe kedelai hitam memberi pengaruh meningkatkan kadar hemoglobin, jumlah eritrosit dan prosen hematokrit serta memberi pengaruh menurunkan jumlah leukosit dan trombosit darah tikus yang diinduksi dengan bakteri EPEC. Kelompok tikus yang mengonsumsi tempe kedelai hitam tidak berpengaruh terhadap kadar IgG dan IgA plasma darah.
\end{abstract}

Kata kunci: Tempe kedelai hitam; hematologi; IgG; IgA

\begin{abstract}
Consumption of black soybean tempe can provide rapid improvement in children with poor nutritional status and/ or suffering from diarrhea. The antioxidant activity of black soybean tempe is higher than yellow soybean tempe. This study aimed to examine the effect of the amount of black soybean tempe in the feed on hematological status, IgG levels, and IgA levels of rat blood. There was a total of 6 groups, each containing 5 rats. The rats were kept in animal laboratories at room temperature $\left(25-27^{\circ} \mathrm{C}\right)$ for 25 days. The six groups were induced Enteropathogenic Escherichia coli (EPEC) suspension with a concentration of 107 CFU / mL of $1 \mathrm{~mL}$ per day for seven days, orally using a feeding tube. Parameters analyzed included hematology status, IgG levels and IgA levels. The administration of black soybean tempe had an effect on increasing hemoglobin levels, the number of erythrocytes and the percentage of hematocrit, and it gave the effect of decreasing the number of leukocytes and platelets of rat blood induced with EPEC bacteria. The group of rats that consumed black soybean tempe had no influence on IgG and IgA levels of blood plasma.
\end{abstract}

Keywords: Black soybean tempe; hematology; IgG; IgA 


\section{PENDAHULUAN}

Kedelai yang difermentasi menjadi tempe memiliki kelebihan, hal ini dapat dilihat dari komposisi zat gizinya, daya cerna protein dan kandungan asam amino esensial yang lebih tinggi, dan rendah zat anti nutrisi seperti antitripsin (menghambat kerja enzim tripsin) dan asam fitat (dapat mengikat mineral). Kandungan komponen antioksidan yang terdapat pada tempe antara lain isoflavon, vitamin E dan $\beta$-karoten. Menurut Nurrahman dkk. $\left(2012^{\mathrm{b}}\right)$, tikus yang pakannya mengandung tempe kedelai hitam meningkat aktivitas dari enzim yang berperan sebagai antioksidan seperti superoksida dismutase dan cederung meningkatkan aktivitas enzim katalase dan glutation peroksidase.

Penelitian yang dilakukan oleh Sudigbia (1996) menyatakan bahwa bayi di bawah lima tahun yang menderita gizi kurang dan diare kronik diberi bubur tempe dapat mempercepat perbaikan gizi, kenaikkan berat badan dan penyembuhan diare dibanding makanan tidak mengandung tempe. Tempe banyak dimanfaatkan oleh petugas gizi di rumah sakit sebagai salah satu bentuk terapi anak yang menderita diare. Hal ini dimungkinan berkaitan dengan pemulihan sistem kekebalan tubuh anak yang cepat, baik secara menyeluruh maupun berada di saluran pencernaan.

Sekarang ini tempe diproduksi dengan bahan dasar dari kedelai kuning, namun tempe juga dapat dibuat dari bahan kedelai hitam. Publikasi dari hasil riset tentang tempe kedalai hitam masih terbatas, kebanyakan tentang tempe yang berasal dari kedelai kuning. Kedelai hitam yang dibuat tempe memiliki sifat fungsional yang lebih baik dibanding tempe kedelai kuning, karena kedelai hitam memiliki kadar fenolik, tanin, antosianin dan isoflavon yang lebih banyak dengan aktivitas antioksidan lebih tinggi (Xu \& Chang, 2007). Menurut Nurrahman dkk. (2012a $)$, tempe kedelai hitam dengan berbagai inokulum yang berbeda memiliki aktivitas antioksidan lebih tinggi dan rasa lebih disukai dibandingkan tempe pada umumnya.

Tingkat proliferasi sel $\mathrm{T}$ pada tikus yang diberi pakan yang terdapat tepung tempe kedelai hitam selama 30 hari menunjukkan lebih tinggi dibanding pakan yang tidak mengandung tempe tersebut, akan tetapi pengaruhnya tidak signifikan pada prolifersi sel B dan kadar IgA sekretori (Nurrahman dkk., 2011). Pakan mengandung tepung tempe kedelai hitam juga meningkatkan prolifersi sel $\mathrm{T}$ pada tikus yang tidak diinfeksi dan yang diinfeksi Salmonella typimurium (Nurrahman dkk., 2011). Penelitian lain konsumsi tepung tempe kedelai hitam menyebabkan peningkatan daya tahan limfosit terhadap hidrogen peroksida dan aktivitas enzim SOD (Nurrahman dkk., 2012b). Hal ini menunjukan bahwa ada komponen di dalam tempe kedelai hitam, kemungkinan adanya kelompok isoflavon, yang mampu menstimulasi limfosit untuk berproliferasi. Dengan penjelasan tersebut dapat disimpulkan bahwa tempe tersebut dapat meningkatkan sistem kekebalan seluler.

Nurrahman dkk. (2011) dan Nurrahman dan Nurhidajah (2014) juga mengatakan bahwa tikus yang pakannya mengandung tepung tempe kedelai hitam pertumbuhan berat badannya lebih tinggi dibanding konsumsi pakan standar. Kemungkinan pemberian tempe kedelai hitam kepada anak yang memiliki status gizi rendah dan/atau menderita diare dapat diperbaiki lebih cepat dibanding konsumsi tempe kedelai kuning, melalui perbaikan kerja sistem imunnya. Namun belum ada data yang mendukung peran tempe kedelai hitam terhadap perbaikan sistem imun penderita diare. Penelitian ini bertujuan untuk mengkaji pengaruh konsumsi pakan yang mengandung tempe kedelai hitam terhadap status hematologi, kadar IgG, dan kadar IgA darah tikus.

\section{BAHAN DAN METODE}

\section{Bahan dan Alat}

Bahan penelitian ini antara lain kedelai hitam, ragi tempe (produksi LIPI), formula pakan tikus berdasar pada AIN 93, tikus (varietas Wistar, sebanyak 30 ekor, kelamin jantan dan berumur 4 sampai 6 minggu), kultur Enteropatogenec Escherichia coli (EPEC), IgG reagen kit dan IgA reagen kit. Peralatan yang dibutuhkan antara lain kandang individu, microplate, microplate reader, micropipette, sentrifus, inkubator dan hematology analyzer.

\section{Prosedur Penelitian}

Tahapan yang dilakukan pada penelitian ini antara lain pembuatan tempe kedelai hitam dengan menggunakan inokulum jadi produksi LIPI (metode Nurrahman dkk., 2011) dan pemeliharaan tikus dengan metode pemeliharaan, pemberian formula pakan dan perlakuan yang sama dengan yang telah dipublikasikan oleh Nurrahman dan Mariyam (2016). Pada pemeliharaan hari ke 25 , tikus diambil darahnya sebanyak $2 \mathrm{~mL}$ untuk dianalisa status hematologi dan dipisahkan plasmanya untuk analisa IgG dan IgA.

\section{Disain Eksperimen}

Disain eksperimen dalam penelitian ini adalah rancangan acak lengkap (RAL) dengan variabel independen formula pakan tikus yang tersusun dari pakan standar dan pakan yang ditambah tepung 
tempe kedelai hitam dengan variasi $25,50,75$ dan $100 \%$ sebagai pengganti kasein. Adapun variabel dependennya status hematologi darah dan kadar IgG dan IgA plasma. Data yang diperoleh diuji secara statistik dengan metode ANAVA faktor tunggal.

\section{HASIL DAN PEMBAHASAN}

\section{Status Hematologi}

Status hematologi darah tikus yang diukur antara lain hemoglobin, eritrosit, leukosit, trombosit dan hematokrit. Analisa dilakukan di Laboratorium Kesehatan Semarang dengan alat Hematology Analyser. Tabel 1 menunjukkan status hematologi tikus yang mengalami perlakuan selama 25 hari.

\section{Hemoglobin}

Hemoglobin adalah salah satu protein di dalam darah yang memiliki peran sebagai alat transportasi oksigen dan karbon dioksida pada proses pernafasan. Hemoglobin menangkap oksigen di rongga alveoli yang terletak di paru-paru dan membawanya ke jaringan yang membutuhkan oksigen. Di jaringan hemoglobin menangkap karbon dioksida kemudian dibawa ke paru-paru untuk dikeluarkan melalui alat pernafasan. Jumlah hemoglobin di dalam darah menunjukkan status kesehatan seseorang. Kadar hemoglobin normal untuk laki-laki $14-18 \mathrm{~g} / \mathrm{dL}$, sedangkan untuk perempuan 12$16 \mathrm{~g} / \mathrm{dL}$. Seseorang yang memiliki darah dengan kadar hemoglobin kurang dari normal dinyatakan menderita anemia.

Kadar hemoglobin tikus percobaan rata-rata antara $13,14 \mathrm{~g} / \mathrm{dL}$ pada kelompok tikus dengan konsumsi pakan mengandung tempe kedelai hitam $50 \%$ pengganti kasein hingga 19,04 g/dL pada kelompok tempe $100 \%$. Kelompok kontrol positif kadar hemoglobin $14,58 \mathrm{~g} / \mathrm{dL}$ dan kontrol negatif 15,72 g/dL. Berdasarkan data tersebut dapat dikatakan semua kelompok tikus memiliki kadar hemoglobin ada yang kurang dari normal dan ada yang lebih, menurut Giknis dan Clifford (2008) kadar hemoglobin normal pada tikus umur 8-16 minggu antara 13,7 sampai $17,6 \mathrm{~g} / \mathrm{dL}$.

Berdasarkan analisa statistik dengan ANOVA menunjukkan ada pengaruh perlakuan terhadap kadar hemoglobin darah $(p<0,05)$. Induksi dengan EPEC tidak mempengaruhi kadar hemoglobin pada kelompok kontrol positif dibanding kontrol negatif, artinya induksi EPEC tikus mengalami penurunan kadar hemoglobin tetapi tidak signifikan. Induksi EPEC pada kelompok tempe $25 \%$ dan $50 \%$ mengalami penurunan kadar hemoglobin signifikan dibandingkan dengan kontrol negatif. Kelompok tikus konsumsi tempe kedelai hitam $75 \%$ memiliki kadar hemoglobin yang hampir sama dengan kontrol negatif, ada perbedaan tetapi tidak signifikan. Pada kelompok tempe $100 \%$ mulai memiliki kadar hemoglobin melebihi dari kontrol negatif. Sepertinya perlakuan konsumsi tempe kedelai hitam mulai menampakan pengaruh positif pada penambahan tempe $75 \%$ pengganti kasein, sedangkan kelompok tempe $25 \%$ dan $50 \%$ pengaruhnya negatif.

Menurut Astuti (1996) setiap $100 \mathrm{~g}$ tempe kering mengandung $9 \mathrm{mg}$ zat besi, 2,87 mg Cu, dan 8,05 mg Zn. Zat besi di dalam tempe lebih mudah diserap oleh usus halus dibanding kedelai. Selama fermentasi tempe total zat besi terlarut meningkat dari $24,29 \%$ pada kedelai yang belum difermentasi menjadi $40,52 \%$ pada tempe yang difermentasikan selama 48 jam. Kejadian anemia pada seseorang ditandai dengan rendahnya kadar hemoglobin di dalam darah. Hemoglobin merupakan senyawa protein kompleks, yang proses sintesanya di dalam tubuh membutuhkan ketersediaan protein, $\mathrm{Fe}$, vitamin $\mathrm{B} 12$, asam folat, $\mathrm{Cu}$ dan $\mathrm{Zn}$. Komponenkomponen tersebut tersedia di dalam tempe sebagai hasil dari proses fermenta.

Tabel 1. Data hemoglobin, leukosit, eritrosit, trombosit dan hematokrit tikus

\begin{tabular}{cccccc}
\hline Perlakuan & $\begin{array}{c}\text { Hemoglobin } \\
(\mathrm{g} / \mathrm{dL})\end{array}$ & $\begin{array}{c}\text { Leukosit } \\
(\text { ribu/ } \mu \mathrm{L})\end{array}$ & $\begin{array}{c}\text { Eritrosit } \\
(\text { ribu/ } \mu \mathrm{L})\end{array}$ & $\begin{array}{c}\text { Trimbosit } \\
(\text { ribu/ } \mu \mathrm{L})\end{array}$ & $\begin{array}{c}\text { Hematokrit } \\
(\%)\end{array}$ \\
\hline Kontrol positif & $14,48^{\mathrm{a}}$ & $1,996^{\mathrm{a}}$ & $8,25^{\mathrm{a}}$ & $1015^{\mathrm{a}}$ & $45,54^{\mathrm{a}}$ \\
Kontrol negatif & $15,72^{\mathrm{a}}$ & $1,960^{\mathrm{a}}$ & $8,77^{\mathrm{a}}$ & $776^{\mathrm{b}}$ & $48,32^{\mathrm{b}}$ \\
Tempe (25\%) & $13,5^{\mathrm{b}}$ & $2,044^{\mathrm{b}}$ & $7,07^{\mathrm{b}}$ & $699^{\mathrm{b}}$ & $45,00^{\mathrm{a}}$ \\
Tempe (50\%) & $13,4^{\mathrm{b}}$ & $1,962^{\mathrm{a}}$ & $7,61^{\mathrm{b}}$ & $818^{\mathrm{b}}$ & $42,18^{\mathrm{a}}$ \\
Tempe (75\%) & $15,6^{\mathrm{a}}$ & $1,974^{\mathrm{a}}$ & $7,86^{\mathrm{c}}$ & $802^{\mathrm{b}}$ & $47,08^{\mathrm{b}}$ \\
Tempe (100\%) & $19,04^{\mathrm{c}}$ & $1,980^{\mathrm{a}}$ & $8,76^{\mathrm{a}}$ & $781^{\mathrm{b}}$ & $49,72^{\mathrm{b}}$ \\
\hline
\end{tabular}

Keterangan: huruf berbeda menunjukkan perbedaan signifikan 


\section{Leukosit}

Leukosit dinamakan juga sel darah putih yang terdiri antara lain neutrofil, eosinofil, basofil, limfosit, dan monosit. Sel tersebut dihasilkan oleh jaringan hemopoetik yang memiliki peran dalam sistem immun seluler dan humoral untuk melawan terjadinya infeksi di dalam tubuh. Untuk manusia dewasa jumlah normal leukosit $4.000-10.000 / \mathrm{mm}^{3}$. Peningkatan dan penurunan jumlah leukosit menunjukkan adanya infeksi atau radang akut, selain itu juga disebabkan obatobatan tertentu.

Jumlah leukosit pada kelompok kontrol negatif sebanyak 1.960 sel per $\mu \mathrm{L}$, sedangkan kelompok tikus yang diinduksi dengan EPEC memiliki jumlah leukosit lebih tinggi (Tabel 3). Jumlah leukosit tertinggi pada kelompok tempe $25 \%$ yaitu 2.044 sel per $\mu \mathrm{L}$, kemudian kelompok kontrol positif sebanyak 1.994 sel per $\mu \mathrm{L}$. Kelompok 50, 75, dan 100\% jumlah leukositnya masingmasing 1.962, 1.974 dan 1.980 sel per $\mu \mathrm{L}$. Menurut Giknis dan Clifford (2008) kadar leukosit normal pada tikus umur 8-16 minggu antara 1.960 sampai 8.250 sel per $\mu \mathrm{L}$, dengan demikian dapat dikatakan semua kelompok tikus yang digunakan dalam penelitian ini dalam keadaan normal.

Berdasarkan analisa statistik dengan ANOVA menunjukkan ada pengaruh perlakuan terhadap jumlah leukosit $(p<0,05)$. Induksi tikus dengan EPEC berdampak pada peningkatan jumlah leukosit secara signifikan, kecuali kelompok tempe $50 \%$. Hal ini menunjukkan bahwa induksi EPEC berakibat meningkatkan jumlah leukosit tikus. Tikus memproduksi leukosit untuk melawan EPEC sehingga jumlah leukosit meningkat. Pengaruh tempe kedelai hitam terhadap jumlah leukosit tidak signifikan dibandingkan kontrol positif, kecuali pada kelompok tempe $25 \%$. Meskipun adanya respon pada kelompok tikus yang diinfeksi dengan EPEC dengan melihat peningkatan jumlah leukosit, namun demikian peningkatan jumlah leukosit masih dikatakan normal.

\section{Eritrosit}

Eritrosit atau sel darah merah merupakan komponen sel terbanyak di dalam darah, warnanya mendominasi keseluruhan darah. Sel darah merah sebagian besar tersusun atas hemoglobin yang berperan utama sebagai transport oksigen. Pemeriksaan terhadap jumlah eritrosit untuk mengetahui status anemia, normal atau polistemia (peningkatan jumlah eritrosit, hemoglobin atau hematokrit. Dalam keadaan normal

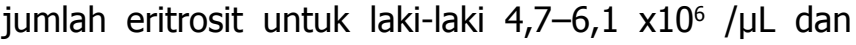
perempuan $4,2-5,4 \times 10^{6} / \mu \mathrm{L}$.

Jumlah eritrosit untuk kelompok kontrol negatif $8,77 \times 10^{6} / \mu \mathrm{L}$. Pada kelompok tikus yang diinduksi dengan EPEC mengalami penurunan jumlah eritrosit baik pada kelompok kontrol positif maupun kelompok perlakuan tempe kedelai hitam. Hal ini berarti induksi EPEC berpengaruh terhadap penurunan jumlah eritrosit. Berdasarkan data tersebut dapat dikatakan semua kelompok tikus memiliki jumlah eritrosit ada yang kurang dari normal, pada kelompok tempe $25 \%$, menurut Giknis dan Clifford (2008) jumlah eritrosit normal pada tikus umur 8-16 minggu antara 7,27 sampai $9,65 \times 10^{6} / \mu \mathrm{L}$.

Berdasarkan analisa statistik dengan ANOVA menunjukkan ada pengaruh perlakuan terhadap jumlah leukosit $(p<0,05)$. Induksi tikus dengan EPEC berdampak pada penurunan jumlah leukosit secara signifikan pada kelompok tempe 25, 50, dan $75 \%$. Kelompok tempe $75 \%$ mengalami kenaikan jumlah eritrosit secara signifikan dibanding kelompok tempe 25 dan 50\%. Sedangkan kelompok kontrol positif dan tempe $100 \%$ terjadi penurunan tidak signifikan. Dengan demikian, dapat dikatakan konsumsi tempe $100 \%$ sebagai pengganti kasein memiliki jumlah eritrosit sama dengan kontrol positif dan kontrol negatif.

\section{Trombosit}

Trombosit atau platelet berperan sebagai komponen darah yang menyebabkan pembekuan darah. Pembekuan darah terjadi bila terjadi luka pada jaringan. Luka yang terjadi menimbulkan kerusakan pada trombosit jaringan, sehingga jaringan mengeluarkan trombosiplastin yang kemudian membentuk trombin dengan cara berinteraksi dengan protrombin dan kalsium. Trombin yang terbentuk bereaksi dengan fibrinogen menghasilkan fibrin, yang kemudian menutup jaringan yang luka (Astawan dkk., 2012). Untuk manusia jumlah trombosit normal di dalam darah adalah 150.000-450.000/ $\mu \mathrm{L}$.

Jumlah trombosit pada kelompok kontrol negatif $776.000 / \mu \mathrm{L}$, sedangkan pada kelompok tikus yang diinduksi dengan EPEC mengalami peningkatan jumlah trombosit kecuali kelompok tempe 25\% (699.000/ $\mu \mathrm{L})$. Jumlah trombosit pada kelompok kontrol positif paling tinggi dibanding kelompok yang lain, yaitu 1.015 .000 / $\mu \mathrm{L}$.

Berdasarkan analisa statistik dengan ANOVA menunjukkan ada pengaruh perlakuan terhadap jumlah trombosit $(p<0,05)$. Induksi tikus dengan EPEC berdampak pada peningkatan jumlah trombosit secara signifikan pada kelompok kontrol positif, sedangkan pada tikus kelompok yang mengonsumsi tepung tempe 50 , 75, dan $100 \%$ ada peningkatan jumlah trombosit tetapi tidak signifikan. Pada kelompok konsumsi tepung tempe $25 \%$ ada penurunan dibanding kelompok kontrol negatif 
tetapi tidak signifikan. Menurut Astawan dkk. (2012) infeksi bakteri EPEC pada usus menyebabkan tubuh mensintesis trombosit untuk mengatasinya, sehingga meningkatkan jumlah trombositnya secara keseluruhan. Namun demikian, peningkatan dan penurunan jumlah trombosit pada kelompok tikus yang diinduksi dengan EPEC dalam interval normal. Menurut Giknis dan Clifford (2008) jumlah trombosit normal pada tikus umur 8-16 minggu antara 638.000 sampai $1.177 .000 / \mu \mathrm{L}$.

\section{Hematokrit}

Hematokrit merupakan hasil sebuah pengukuran yang menyatakan perbandingan jumlah sel eritrosit dalam $100 \mathrm{~mL}$ darah, dengan satuan persen. Pengukuran ini dilakukan untuk mendeteksi adanya ketidaknormalan yang mengganggu sel darah merah, baik berlebih atau berkurang. Beberapa faktor yang menyebabkan hematokrit berkurang antara lain anemia, kerusakan sel darah merah, kekurangan zat gizi (malnutrisi) dan konsumsi air berlebih. Sedangkan faktor-faktor yang menyebabkan hematokrit meningkat antara lain mengalami penyakit jantung atau paru-paru, kekurangan cairan, dan hipoksia (keadaan kurang oksigen). Dalam keadaan normal pria dewasa mempunyai hematokrit 40-50\% dan pada perempuan dewasa $36-44 \%$.

Nilai hematokrit pada kelompok kontrol negatif adalah $48,32 \%$. Sedangkan pada kelompok tikus yang diinduksi dengan EPEC mengalami penurunan nilai hematokrit kecuali kelompok tempe $100 \%$, yaitu $49,72 \%$. Nilai hematokrit pada darah tikus dari kelompok kontrol positif, tepung tempe kedelai hitam 25, 50, dan $75 \%$ masing-masing secara berurutan adalah 45,54, 45,00, 42,18 , dan $47,08 \%$. Namun demikian, peningkatan dan penurunan nilai hematokrit pada kelompok tikus yang diinfeksi dengan EPEC dalam interval normal. Menurut Giknis dan Clifford (2008) nilai hematokrit normal pada tikus umur 8-16 minggu antara 39,6 sampai $52,5 \%$.

Berdasarkan analisa statistik dengan ANOVA menunjukkan ada pengaruh perlakuan terhadap nilai hematokrit $(p<0,05)$. Induksi tikus dengan EPEC berdampak pada penurunan nilai hematokrit secara signifikan pada kelompok kontrol positif, tempe 25 dan $50 \%$. Penurunan ini terjadi karena seluruh potensi tubuh digunakan untuk menetralisir terjadinya induksi oleh EPEC, sehingga nilai hematokrit rendah dibanding kelompok kontrol negatif.

Pada kelompok $75 \%$ ada penurunan tetapi tidak signifikan dan kelompok tempe $100 \%$ ada peningkatan tapi tidak signifikan. Dengan demikian, hal ini dapat dikatakan bahwa konsumsi tempe kedelai hitam dengan konsentrasi 75 dan $100 \%$ pengganti kasein memiliki nilai hematokrit sama dengan kelompok tikus yang tidak diinduksi dengan EPEC. Jumlah tempe kedelai hitam yang dikonsumsi oleh kelompok tersebut mampu menghambat infeksi terhadap EPEC.

\section{Kadar IgG dan IgA Plasma Darah}

Apabila sistem kekebalan tubuh terpapar oleh antigen (zat yang dianggap benda asing) maka ada dua jenis respon tubuh yang mungkin terjadi, yaitu respon imun spesifik dan non spesifik. Respon imun yang bersifat non spesifik merupakan imunitas natural/alamiah yang dapat berinteraksi dengan antigen walaupun sebelumnya belum pernah terpapar. Manifestasi dari sistem imun non spesifik berupa fagositosis dan reaksi inflamasi. Sel-sel yang tergolong

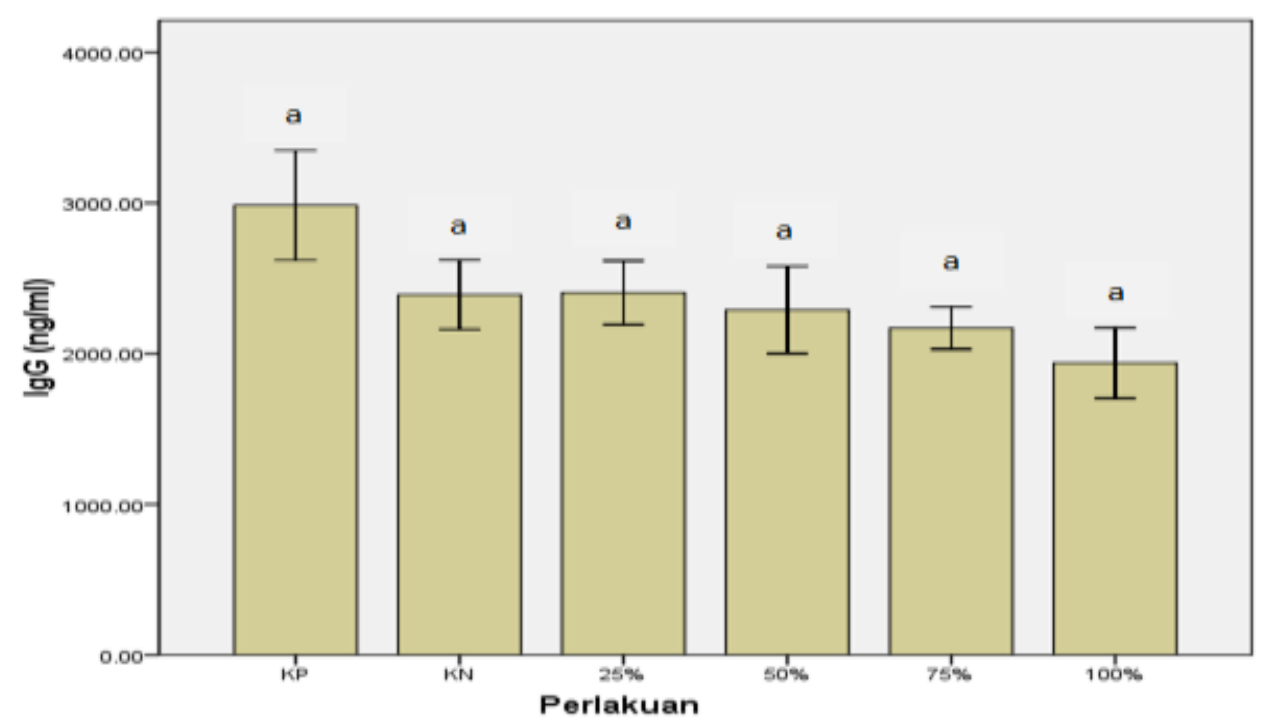

Gambar 1. Pengaruh diit terhadap kadar IgG plasma (KP=kontrol positif, $\mathrm{KN}=$ kontrol negatif) 
pada sistem imun ini antara lain neutrofil, eosinofil, basofil, mastosit, monosit dan makrofag. Imun spesifik merupakan respon terhadap antigen yang sebelumnya pernah terpapar. Limfosit merupakan sel imun yang tergolong dalam sistem imun spesifik yang mampu mengenali secara spesifik terhadap antigen yang masuk ke dalam tubuh, dan membentuk memori terhadap antigen tersebut (Abbas dkk., 2007).

Imunoglobolin merupakan salah satu dari respon imun spesifik, yang diproduksi oleh sel B merupakan bagian dari respon spesifik dengan adanya antigen. Ada lima jenis imunoglobolin, yaitu IgA, IgD, IgE, IgG dan IgM. Peran dari antibodi ini mampu menghambat pertumbuhan mikroorganisme patogen yang menginfeksi tikus. Pada percobaan ini yang dianalisa IgG dan IgA plasma berasal dari darah tikus yang dikenai perlakuan formula pakan mengandung tempe kedelai hitam dan diinduksi dengan bakteri EPEC, dengan kontrol negatif dan positif. Gambar 1 menunjukkan pengaruh perlakuan diit terhadap kadar IgG plasma darah.

Kadar IgG plasma darah tikus kelompok kontrol negatif sebesar $2390 \mathrm{ng} / \mathrm{mL}$. Kelompok tikus yang mengalami induksi oleh bakteri EPEC pada kelompok positif dan tempe $25 \%$ meningkat masing-masing jadi 2983 dan $2403 \mathrm{ng} / \mathrm{mL}$ dan kelompok yang mengalami perlakuan diit tempe kedelai hitam 50, 75 dan, 100\% mengalami penurunan kadar IgG masing-masing 2290, 2170, dan $1936 \mathrm{ng} / \mathrm{mL}$. Berdasarkan analisa statistik dengan ANOVA menunjukkan tidak ada pengaruh perlakuan terhadap kadar IgG plasma darah $(p>0,05)$. Induksi tikus dengan EPEC berdampak pada kenaikan dan penurunan kadar IgG plasma darah tetapi tidak signifikan.
Gambar 2 menunjukkan pengaruh diit terhadap kadar IgA plasma darah tikus. Kadar IgA plasma darah tikus kelompok kontrol negatif sebesar $1236 \mathrm{ng} / \mathrm{mL}$. Kelompok tikus yang mengalami induksi oleh bakteri EPEC pada kelompok positif, tempe $25 \%$ dan tempe $75 \%$ meningkat masing-masing jadi 1492, 1497, dan $1332 \mathrm{ng} / \mathrm{mL}$ dan kelompok yang mengalami perlakuan diit tempe kedelai hitam 50 dan 100\% mengalami penurunan kadar IgG masing-masing 1019 dan 1190 $\mathrm{ng} / \mathrm{mL}$. Berdasarkan analisa statistik dengan ANOVA menunjukkan tidak ada pengaruh perlakuan terhadap kadar IgA plasma darah $(p>0,05)$. Induksi tikus dengan EPEC ada berdampak pada kenaikan dan penurunan kadar IgA plasma darah tetapi tidak signifikan.

Jika dilihat dari selisih kenaikan dan penurunan kadar IgG dan IgA antar kelompok dibanding kelompok kontrol negatif, maka kelompok positif memiliki selisih yang paling banyak. Hal ini terjadi kemungkinan disebabkan induksi bakteri EPEC sebagai antigen berpengaruh dalam produksi antibodi. EPEC mampu berkembang di jaringan menyebabkan infeksi yang dibuktikan dengan penampilan feses, kadar air, jumlah leukosit dan trombosit pada kelompok kontrol positif lebih tinggi dibanding kelompok yang lain.

Kelompok yang mengonsumsi tempe ada kenaikan dan penurunan dengan selisih kadar IgG dan IgA yang relatif sedikit dibanding kelompok konrol negatif. Hal ini menunjukkan bahwa tempe kedelai hitam mampu mencegah EPEC untuk menginfeksi jaringan sehingga tidak terjadi peningkatan dan penurunan kadar IgG plasma darah secara signifikan.

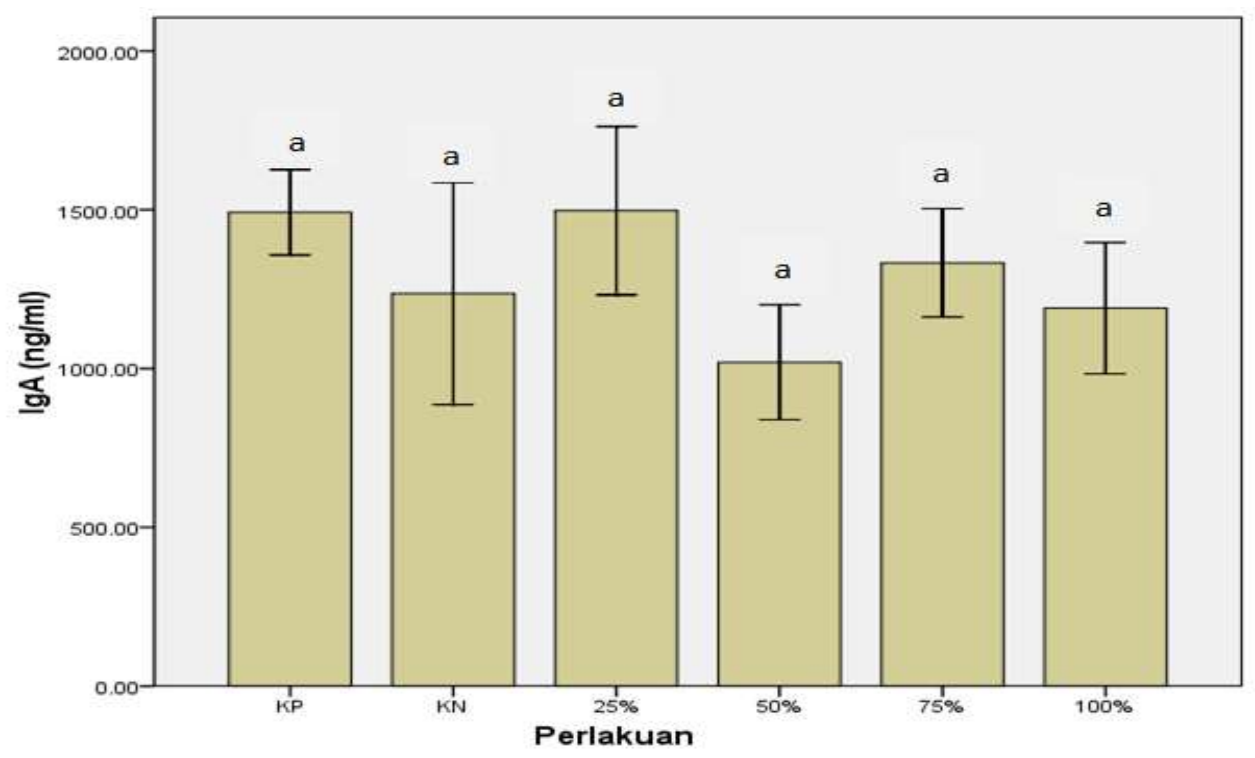

Gambar 2. Pengaruh diit terhadap kadar IgA plasma (KP=kontrol positif, KN=kontrol negatif) 


\section{KESIMPULAN}

Ada pengaruh pemberian formula pakan mengandung tempe kedelai hitam terhadap kadar hemoglobin, jumlah leukosit, jumlah eritrosit, jumlah trombosit dan prosen hematokrit darah tikus yang diinduksi dengan bakteri EPEC. Tidak ada pengaruh pemberian formula pakan yang mengandung tempe kedelai hitam terhadap kadar IgG dan IgA plasma darah tikus yang diinduksi dengan bakteri EPEC.

\section{KONFLIK KEPENTINGAN}

Penulis menyatakan bahwa artikel ini asli, belum pernah dipublikasikan, dan bebas dari konflik kepentingan.

\section{DAFTAR PUSTAKA}

Abbas, A.K., A.H. Lichtman, and S. Pillai. (2007). Cellular and Molecular Immunology. Saunders Elsevier, Philadelphia.

Astawan, M, T. Wresdiyati, Suliantari, dan Y.MS. Nababan. (2012). Yoghurt sinbiotik berbasis probiotik lokal dapat mencegah diare dan mengubah status hematologi tikus. Jurnal Veteriner, 13(2), 145-153.

Astuti, M. (1996). Tempe dan antoksidan prospek pencegahan penyakit degeneratif. Dalam. Sapuan dan N. Soetrisno (eds.). 1996. Bunga Rampai Tempe Indonesia, Jakarta, hal. 133-146. Yayasan Tempe Indonesia, Jakarta.

Giknis, M.L.A and C.B. Clifford, D.V.M. (2008). Clinical Laoratory Parameters for Crl:WI(Han). Charles River Laboratories, Wilmington.
Nurrahman. (2012). Potensi Tempe Kedelai Hitam dalam meningkatkan Kadar IgA Sekretori dan Proliferasi Limfosit in vivo. Disertasi. Fakultas Teknologi Pertanian UGM, Yogyakarta.

Nurrahman, M. Astuti, Suparmo dan M.H.N.E. Soesatyo. (2011). The effect of black soybeans tempe and it's ethanol extract on lymphocyte proliferation and IgA secretion in Salmonella typhimurium induced rat. Afri. J. Food Scie., 5(14), 775-779.

Nurrahman, M. Astuti, Suparmo dan M.H.N.E. Soesatyo. $\left(2012^{a}\right)$. Pertumbuhan jamur, sifat organoleptik dan aktivitas antioksidan tempe kedelai hitam yang diproduksi dengan berbagai jenis inokulum. J. Agritech, 32(1), 60-65.

Nurrahman, M. Astuti, Suparmo dan M.H.N.E. Soesatyo. $\left(2012^{b}\right)$. Peran tempe kedelai hitam dalam meningkatkan aktivitas enzim antioksidan dan daya tahan limfosit terhadap hidrogen peroksida in vivo. Proseding Seminar Hasil-hasil Penelitian UNIMUS, Semarang.

Nurrahaman dan Nurhidajah. (2014). Pengaruh Konsumsi Tempe Kedelai Hitam terhadap Berat Badan Tikus. Proseding Seminar Hasil-hasil Penelitian UNIMUS, Semarang.

Sudigbia, P. (1996). Tempe dalam Penatalaksanaan Diare Anak. Dalam. Sapuan dan N. Soetrisno (eds.). 1996. Bunga Rampai Tempe Indonesia, Jakarta, hal. 71-82. Yayasan Tempe Indonesia, Jakarta.

Xu, B.J. and S.K.S. Chang. (2007). A Comparative study on phenolic profils and antioxidant of legums as affected by extraction solvents. J. Food Sci., 72(2):159-166. DOI: 10.1111/j.1750-3841.2006.00260.x 